\title{
Ecology and Species Composition of Fresh Water Snails in Amassoma Community and Niger Delta University Campuses, Bayelsa State, Nigeria
}

\author{
Ebenezer Amawulu*, Ndubuisi Uchechi Assumpta \\ Department of Biological Sciences, Niger Delta University, Wilberforce Island, Bayelsa State, Nigeria \\ Email: *ebenezeramawulu@gmail.com
}

How to cite this paper: Amawulu, E. and Assumpta, N.U. (2021) Ecology and Species Composition of Fresh Water Snails in Amassoma Community and Niger Delta University Campuses, Bayelsa State, Nigeria. Open Journal of Ecology, 11, 86-93. https://doi.org/10.4236/oje.2021.111008

Received: December 5, 2020

Accepted: January 22, 2021

Published: January 25, 2021

\section{Copyright $\odot 2021$ by author(s) and} Scientific Research Publishing Inc. This work is licensed under the Creative Commons Attribution International License (CC BY 4.0).

http://creativecommons.org/licenses/by/4.0/

(c) (i) Open Access

\begin{abstract}
The knowledge about the population dynamics of freshwater snail intermediate host and their roles in disease transmission is little known in Bayelsa State. This study investigated the species composition of fresh water snail intermediate host in Amassoma community and the Niger Delta University Campuses during August 2019-October 2019 across five locations (Main campus Hostel, E.T.F Building, Ogboebi-Ama, Efeke-Ama, Ogbopina). Snails were collected from the water bodies with the aid of a scooping net and hand picking. The morphological identification of the snail intermediate host followed standard procedures. From the result, five hundred and seventy-one freshwater snails belonging to four genera and five species were recorded. The presence of Lymnae and Bulinus in the locations highlights foci for fascioliasis and schistosomiasis. The presence of Melanoides spp. is novel in Bayelsa State. The public health implications of these snails have called for timely control intervention.
\end{abstract}

\section{Keywords}

Species Composition, Fresh Water Snail, Melanoides spp., Schistosomiasis, Fascioliasis, Bayelsa State

\section{Introduction}

Fresh water snails (family: Planorbidae) are intermediate hosts of several snails borne diseases of human and veterinary importance [1]. In Africa alone, >350 species of fresh water snail intermediate host of medical and veterinary importance have been estimated [2]. Common among the fresh water snail hosts are; 
Biomphalaria which serves as intermediate hosts for Schistosoma mansoni; Bulinus globossus as the intermediate hosts for Schistosoma haematobium, and $S$. intercalatum; Oncomelania serves as the intermediate host for Schistosoma japonicum [3]. Importantly, Melanoides spp. alone serves as intermediate host for more than 6 diseases in mammals and humans [4]. These diseases include Angiostrongyliasis, Clonorchiasis, Fascioliasis, Fasciolopiasis, Opisthrochiasis, Paragonimiasis and Schistosomiasis. The snail borne parasites are transmitted through contact with parasite contaminated water body [5]. Environmental modification and poor drainage system are factors that increase the density of the snail intermediate host, while lack of health education on the choice of water body for recreational purposes predisposes people to the risk of the infection [6]. More than 207 million people representing 85\% of those who live in endemic area of Africa, are infected with snail borne infections and over 700 million people in 76 countries are at risk of infection. In Nigeria, the population density of the snail intermediate host has been studied [7] [8] [9] [10]. The prevalence of fresh water snail intermediate host has been reported in Yenagoa metropolis [11]. However, there is no available literature that has described the population dynamics of fresh water snail in Amassoma community and Niger Delta University in a single report. Amassoma is the host community of the Niger Delta University, Bayelsa State. The population of students within and outside the community has increased as the age of the university increases. The several environmental modifications within the school premises have created a favorable breeding ground for fresh water snails. The knowledge about the population and species composition of fresh water intermediate host in an environment that is experiencing human population expansion is a basic pre-requisite for initiating control intervention of snail borne diseases [12]. However, the information on the population dynamics of fresh water snails is not known by the Niger Delta University and its environment. This is a novel investigation on species composition of fresh water snails' intermediate host in the Niger Delta University and Amassoma Community. The result of the study shall establish the current status of snail intermediate host in Amassoma community. The result can also possibly advise the community leader, and the Niger Delta University in Amassoma community the need to develop and implement long-term control strategy across the different location in the community.

\section{Materials and Methods}

\subsection{Study Area}

Amassoma community $\left(4^{\circ} 57^{\prime}-4^{\circ} 58^{\prime} \mathrm{N}\right.$ and $\left.16^{\circ} 9^{\prime}-6^{\circ} 10^{\prime} \mathrm{E}\right)$ is an ancient community in the Southern Ijaw Local Government Area of Bayelsa State. It is 20 kilometers from Yenagoa, the state capital of Bayelsa State, Nigeria. The area has humid semi-hot equatorial climate of the Af type of Koppen's system. Detail of the study location has been described [13]. The climate of the area is characterized by a dry season (November-March) and wet season (April-October). The 
annual rainfall varies between 2500 - $3000 \mathrm{~mm}$. Subsistent farming and fishing are the two occupations engaged by the community. Farming is done by the females while fishing is predominantly a male occupation and is done intensively at night. The main sources of water are rivers, rain and a few boreholes owned by some individuals. Much of the area is permanently waterlogged thereby becoming conductive for proliferation of snail intermediate host. The vegetation is fresh-water swampy forest. Settlement pattern is a clustered type and people are confined to families and compounds. Some houses bear reminiscent of traditional architecture with mud walls and thatched roofs.

\subsection{Methods of Snail Collection, Preservation and Identification of Snails}

Samples were all water bodies; gutter/drainage, excavation, water pool and river/stream. The water bodies were sampled for the presence of fresh water snails. The snails were collected using two methods: scooping and hand picking. The procedures for collection of snails followed standard procedures in Harman and Berg [14]. The method used for sample collection depends on the depths and sizes of the water bodies. The method of snail collection is shown in Figure 1. The snails caught were preserved in plastic containers containing clay or sandy soil and transported to the laboratory for macroscopic identifications. The identification of snails followed standard keys [15].
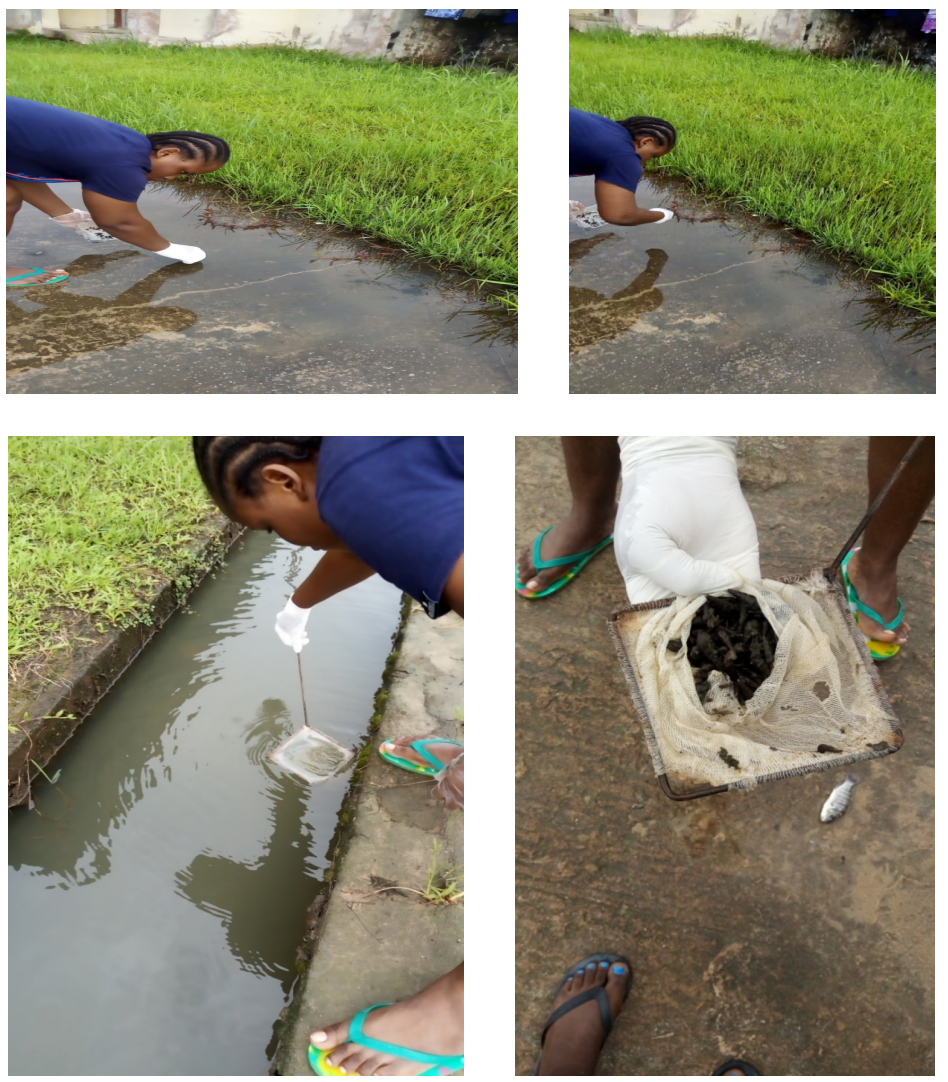

Figure 1. Method of the collection of snail samples. 


\subsection{Data Analysis}

Data entry was done using Microsoft excel and analysis was done using the SPSS software version 20. Descriptive statistics were calculated for background variables using simple percentages Relationship between variables was obtained using ANOVA at confidence level of $\mathrm{p}=0.05$.

\section{Results and Discussion}

Five hundred and sixty-one fresh water snail intermediate hosts in 5 genera were collected from five locations during August, 2019-October 2019. The snails' genus was; Lymnae, Bulinus, Pila and Melanoides (Figure 2). The prevalence of the snail species in order of increasing abundance as shown in Figure 3 are $B u$ linus globosus (14.8\%), B. forskalii (0.12\%), Lymnae natalensis (47.11\%), Pila sp. (5.43\%) and Melanoides spp. (3.07\%). The species composition varied across locations (Figure 4). Bulinus forskalii were exclusive in Ogboebi-Ama while Lymnae natalensis were cosmopolitan across locations. Melanoides spp. were abundance in all other locations except Ogboebi-Ama. Two microhabitats (Gutter and Water pool) of the fresh water snails were identified in the Amassoma community and the University campuses. Although, the fresh water snail showed habitat preferences, its abundance varied significantly across the water bodies $(\mathrm{p}<0.05)$. The water pool was a repository for all kinds of snail species collected while Lymnae natalensis and Melanoides were exclusive in the gutter (Table 1).

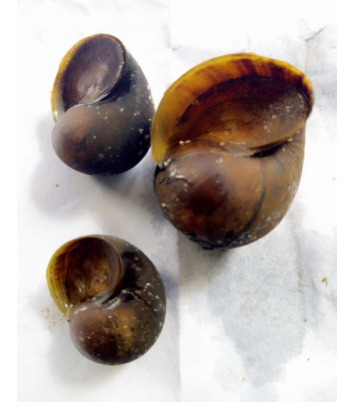

(a)

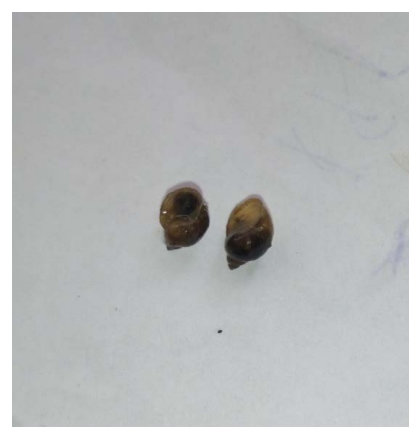

(c)

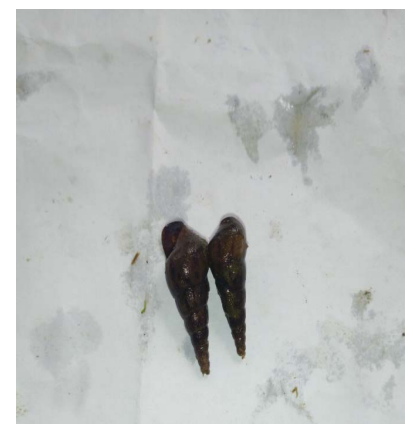

(b)

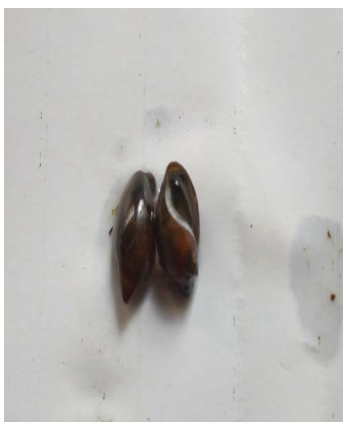

(d)

Figure 2. Snail samples collected from the sample location. Aberpetural and Apertural: (a) Pila; (b) Melanoides; (c) Lymnae natalensis, (d) Bulinus globossus. 


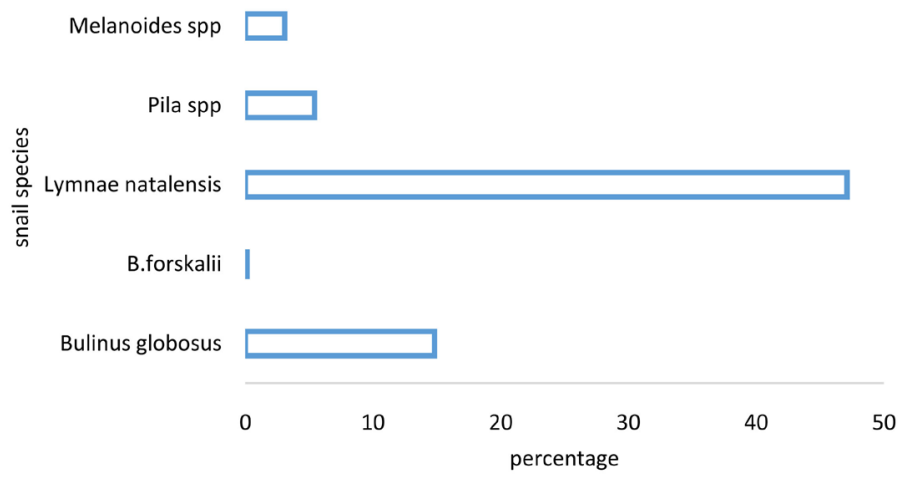

Figure 3. Over all prevalence of fresh water snail collected from Amassoma community and Niger Delta campuses during.

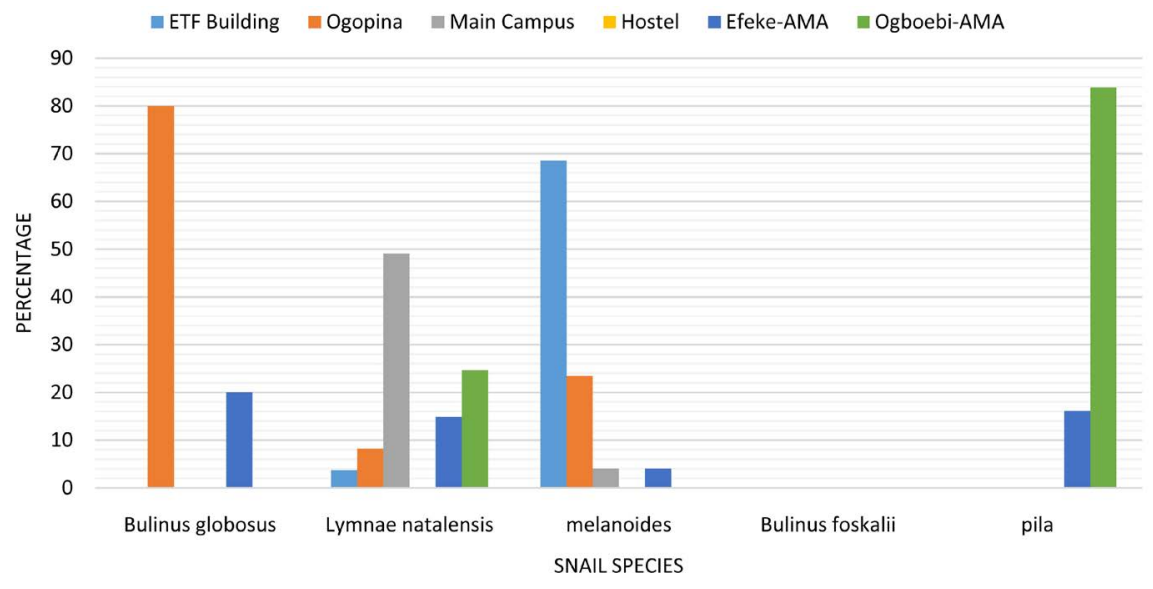

Figure 4. Prevalence of the snail species collected across locations.

Table 1. Species abundance by micro-habitat.

\begin{tabular}{ccccccc}
\hline & \multicolumn{5}{c}{ Species No. (\%) } & \multirow{2}{*}{ Total } \\
\cline { 2 - 6 } Microhabitat & $\begin{array}{c}\text { Bulinus } \\
\text { globosus }\end{array}$ & $\begin{array}{c}\text { Lymnaea } \\
\text { natalensis }\end{array}$ & $\begin{array}{c}\text { Melanoides } \\
\text { spp. }\end{array}$ & $\begin{array}{c}\text { Bulinus } \\
\text { forskalii }\end{array}$ & Pila & \\
\hline Gutter & - & $142(52.79 \%)$ & $127(72.57 \%)$ & - & - & $269(44.59)$ \\
Water pool & $85(29.1)$ & $127(47.21 \%)$ & $48(27.42 \%)$ & $1(100)$ & $31(100)$ & $292(51.8 \%)$ \\
Total & 85 & 269 & 175 & 1 & 31 & 561 \\
\hline
\end{tabular}

The presence of the five snails' intermediate host Bullins globosus, B. forskali, Lymnae natalensis and Melanoides spp. is an indication that the Niger Delta University school environment and Amassoma community can serve as a repository for different kinds of snail intermediate host that transmit different types of snail borne infections. The abundances of snails in a single environment have been reported elsewhere [8] [16]. The spatial distribution of Bulinus globosus and Lymnae natalensis around human environment in the study location highlighted their local risk of fascioliasis and urinary schistosomiasis. The abundance of these snail species may be connected with the suitable water chemistry of the environment. Although, the physiochemical analysis of the water body 
was not undertaken in this present study, several other studies have shown that the abundances of fresh water snail in an environment are related to the velocity of the water [17] as well as the sanitary situation of the water body [5].

The presence of Melanoides spp. within the school premises and in Amassoma community is a novel report in Bayelsa State. Melanoides spp. is an intermediate host for several parasites such as Paragonimus westermani, Clonorchis sinensis, Angiostrongylus cantonensis, Haplorchis pumilio [18] [19] and may play important roles in the transmission of different trematodes parasitic diseases in human, fish and birds [20]. The Niger Delta University environment as well as the Amassoma community has low table water, which became water log at the onset of every raining season. These environments may therefore serve as a repository for the outbreak and spread of snail borne diseases once an infection is initiated.

\section{Conclusion}

This study has identified five fresh water snail: Bulinus globosus, B. forskalii, Lymnae natalensis, Pila sp. and Melanoides spp. Bulinus globosus, B. forskalii, Lymnae natalensis and Melanoides spp. have been reported elsewhere to be of medical and veterinary importance. Their presence in the Niger Delta University campuses and Amassoma community is an indicator for transmission when the needed parasites are introduced into the environment. It is recommended therefore that individual should take cognizance of the possibility of snail borne infections in the community and redirect their water recreational activities. Government and school authority should also make functional drainages within the university environment so as to reduce the establishment of the snails borne diseases in the university community in the nearest future. Further study should also be carried out to establish snail borne infections in the snail and human within and around the school campuses.

\section{Acknowledgements}

We are sincerely grateful to the head of Niger Delta University and Amassoma community for allowing us carried the investigation in their environment.

\section{Conflicts of Interest}

The authors declare no conflicts of interest regarding the publication of this paper.

\section{References}

[1] Akande, I.S. and Odetola, A.A. (2011) Comparative Studies of Two Fresh Water Snail Distributions and Physico-Chemical Parameters in Selected Human Schistosomiasis. Nigerian Journal of Parasitology, 32, 169-174.

[2] Yves, B.K., Edia, E.O., Felix, K.K., Cyrille, K.N., Dramane, D. and Allassana, O. (2013) Spatial Distribution Africa Pattern of Freshwater Mollusks in Me, Agenby and Banco Basin (Ivory Coast; West). Bulletin of Environment, Pharmacology and 
Life Sciences, 2, 146-151.

[3] Keiser, J. and Utzinger, J. (2005) Emerging Foodborne Trematodiasis. Emerging Infectious Diseases, 11, 1507-1514. https://dx.doi.org/10.3201/eid1110.050614

[4] Emil, M.H. and Sofía, J. (2012) Snails Blology, Ecology and Conservation: Animal Science, Issues and Professions. Nova Science Publishers, New York, 1-105.

[5] Idogho, P.O., Yahaya, O. and Dagona, A.G. (2013) Modelling Water-Sanitation Relationship in Edo State, Nigeria. Advancement in Scientific and Engineering Research, 2, 44-51.

[6] Simoonga, C., Utzinger, J. and Brooker, S. (2009) Remote Sensing, Geographical Information System and Spatial Analysis for Schistosomiasis Epidemiology and Ecology in Africa. Parasitology, 136, 1683-1693. https://doi.org/10.1017/S0031182009006222

[7] Mafiana, C.F., Ekpo, U.F. and Ojo, D.A. (2003) Urinary Schistosomiasis in Preschool Children in Settlements around Oyan Reservoir in Ogun State, Nigeria: Implications for Control. Tropical Medicine and International Health, 8, 78-82. https://doi.org/10.1046/j.1365-3156.2003.00988.x

[8] Ngele, K.K., Kalu, E.O., Ukwe, M.C. and Onyeuwu, C.N. (2012) A Survey of Freshwater Snails: The Intermediate Hosts of Schistosomiasis in Bende L.G.A., Abia State Nigeria. International Journal of Science and Nature, 3, 879-882.

[9] Salawu, O.T. and Odaibo, A.B. (2014) The Bionomics and Diversity of Freshwater Snails Species in Yewa North, Ogun State, Southwestern Nigeria. Helminthologia, 51, 337-344.

[10] Owojori, O.J., Asaolu, S.O. and Ofoezie, I.E. (2006) Ecology of Fresh Water Snails in Opa Reservoir and Research Farm Ponds at Obafemi Awolowo University Ile-Ife, Nigeria. Journal of Applied Sciences, 6, 3004-3015. https://dx.doi.org/10.3923/jas.2006.3004.3015

[11] Amawulu, E., Eze, C.N. and Obi, B.B. (2018) Spatial Distribution of Fresh Water Snail Intermediate Host in Yenagoa Metropolis, Bayelsa State, Nigeria. Journal of Parasitology and Vector Biology, 10, 73-78. https://doi.org/10.5897/JPVB2018.0320

[12] Abubakar, I.U, Tukur, A. and Ahmed, A. (2019) Studies on Distribution and Abundance of Freshwater Snail Intermediate Hosts of Schistosomiasis along Kwanar Areh Dam in Rimi L.G.A. of Katsina State. Journal of Parasitology and Vector Biology, 11, 26-35. https://doi.org/10.5897/JPVB2018.0345

[13] Ebenezer, A., Thomas, C. and Amain, A. (2020) Effect of Physico Chemical Parameters on Mosquito Larva Population in the Niger Delta University Campuses, Bayelsa State, Nigeria. International Journal of Zoological Research, 16, 63-68. https://dx.doi.org/10.3923/ijzr.2020.63.68

[14] Harman, W.N. and Berg, C.O. (1971) The Freshwater Gastropod of Central New York with Illustrated Keys to the Genera and Species. Cornell University Agricultural Experiment Station, Ithaca.

[15] Mandahl-Barth, G. (1962) Key to the Identification of East and Central African Freshwater Snails of Medical and Veterinary Importance. Bulletin of the World Health Organization, 27, 135-150.

[16] Gabriel, O.D., Frank, B.G., Douglas, N.A., Ally-Said, M., Paul, O.A., Samson, O.A., Collins, O., Canisius, K.K., Phillip, O.O. and Ayub, V.O.O. (2014) Distribution and Abundance of Schistosomiasis and Fascioliasis Host Snails along the Mara River in Kenya and Tanzania. Ecology and Epidemiology, 4, Article No. 24281. https://doi.org/10.3402/iee.v4.24281 
[17] Jones, H.R.R. (1993) Water Velocity as a Control of Aquatic Snails in Concrete Canal Systems for Irrigation (PhD Dissertation). Loughborough University of Technology, Loughborough.

[18] Rader, R.B., Belk, M.C. and Jane Keleher, M. (2003) The Introduction of an Invasive Snail (Melanoides tuberculata) to Spring Ecosystems of the Bonneville Basin, Utah. Journal of Freshwater Ecology, 18, 647-657. https://doi.org/10.1080/02705060.2003.9664007

[19] Alexandre, G., Cesar, L.P., da Silva, A.C., Geórgia, B.E. and Leal, D.F.B. (2005) Habitat Preference of Freshwater Snails in Relation to Environmental Factors and the Presence of the Competitor Snail Melanoides tuberculatus (Müller, 1774). Memórias do Instituto Oswaldo Cruz, 100, 169-176. https://doi.org/10.1590/S0074-02762005000200010

[20] Wingard, G.L., Murray, J.B., Schill, W.B. and Phillips, E.C. (2008) Red-Rimmed Melania (Melanoides tuberculatus) - A Snail in Biscayne National Park, Florida-Harmful Invader or Just a Nuisance? U.S. Geological Survey Fact Sheet 2008-3006, 6 p. https://pubs.usgs.gov/fs/2008/3006/ 